\title{
Systematic Review of the Epidemiology of Complicated Peptic Ulcer Disease: Incidence, Recurrence, Risk Factors and Mortality
}

\author{
James Y. Lau ${ }^{a}$ Joseph Sung ${ }^{b}$ Catherine Hillc Catherine Henderson ${ }^{c}$ \\ Colin W. Howden ${ }^{d}$ David C. Metz ${ }^{e}$ \\ a Department of Surgery and ' Institute of Digestive Disease, Chinese University of Hong Kong, Hong Kong, SAR, \\ China; ${ }^{C}$ Research Evaluation Unit, Oxford PharmaGenesis ${ }^{\mathrm{TM}}$ Limited, Oxford, UK; ${ }^{\mathrm{d}}$ Division of Gastroenterology, \\ Feinberg School of Medicine, Northwestern University, Chicago, III., and e Department of Gastroenterology, \\ Hospital of the University of Pennsylvania, Philadelphia, Pa., USA
}

\section{Key Words}

Peptic ulcer disease • Hemorrhage • Perforation •

Mortality $\cdot$ Recurrence $\cdot$ Epidemiology

\begin{abstract}
Background/Aims: The incidence of uncomplicated peptic ulcer has decreased in recent years. It is unclear what the impact of this has been on the epidemiology of peptic ulcer complications. This systematic review aimed to determine the incidence, recurrence and mortality of complicated peptic ulcer and the risk factors associated with these events. Methods: Systematic PubMed searches. Results: Overall, 93 studies were identified. Annual incidence estimates of peptic ulcer hemorrhage and perforation were 19.4-57.0 and 3.8-14 per 100,000 individuals, respectively. The average 7-day recurrence of hemorrhage was $13.9 \%$ (95\% Cl: $8.4-$ 19.4), and the average long-term recurrence of perforation was $12.2 \%$ (95\% Cl: 2.5-21.9). Risk factors for peptic ulcer complications and their recurrence included nonsteroidal anti-inflammatory drug and/or acetylsalicylic acid use, Helicobacter pylori infection and ulcer size $\geq 1 \mathrm{~cm}$. Proton pump inhibitor use reduced the risk of peptic ulcer hemorrhage. Average 30-day mortality was $8.6 \%$ (95\% Cl: 5.8-11.4) after hemorrhage and $23.5 \%$ (95\% Cl: $15.5-31.0)$ after perforation.
\end{abstract}

Older age, comorbidity, shock and delayed treatment were associated with increased mortality. Conclusions: Complicated peptic ulcer remains a substantial healthcare problem which places patients at a high risk of recurrent complications and death.

Copyright $\odot 2011$ S. Karger AG, Basel

\section{Introduction}

The incidence and prevalence of uncomplicated peptic ulcer have decreased in recent years, largely because of the availability of treatment to eradicate Helicobacter $p y$ lori and the decreasing prevalence of $H$. pylori infection [1-4]. However, the use of acetylsalicylic acid (ASA) and other nonsteroidal anti-inflammatory drugs (NSAIDs) that are associated with adverse gastrointestinal events [5] is becoming more widespread [6]. It is therefore possible that there may have been no corresponding decrease in peptic ulcer complications such as upper gastrointestinal hemorrhage or perforation.

These complications of peptic ulcer disease have a substantial economic impact. The total cost of peptic ulcer disease in the USA, incorporating both direct costs and loss of work productivity, has been estimated to be USD

\section{KARGER}

Fax +4161306 1234 E-Mail karger@karger.ch www.karger.com
(C) 2011 S. Karger AG, Basel 0012-2823/11/0842-0102\$38.00/0

Accessible online at:

www.karger.com/dig
Dr. James Y. Lau

Department of Surgery

Chinese University of Hong Kong

Sha Tin, Hong Kong, SAR (China)

Tel. +852 2632 1411, E-Mail laujyw @ surgery.cuhk.edu.hk 
5.65 billion per year [7]. It is likely that disease-related complications contribute substantially to these costs. A study in the Netherlands calculated the per person costs of hemorrhage, perforation, or a combination of both to be EUR 12,000, EUR 19,000 and EUR 26,000, respectively [8].

The aim of this review is to determine the incidence and recurrence rate of complications associated with peptic ulcer disease in recent years, and to identify risk factors associated with these complications. We also set out to evaluate the mortality associated with these complications and the risk factors associated with this mortality.

\section{Materials and Methods}

The PubMed database was searched for articles that reported the incidence, mortality and associated risk factors for peptic ulcer complications (fig. 1). These searches were performed using the following search string: (peptic ulcer AND obstruction) OR gastric obstruction OR gastric outlet obstruction OR peptic ulcer hemorrhage OR peptic ulcer bleed OR peptic ulcer bleeding OR upper GI bleed OR peptic ulcer perforation AND (incidence OR cohort study OR mortality OR prognosis OR prevalence OR cross-sectional study OR occurrence). We limited our searches to studies in humans that were published in the English literature between 1997 and 2007. Citation list searches were also used to identify additional references.

Studies were reviewed manually first by title and abstract and then by full manuscript. Manuscripts were excluded if their study topic was irrelevant, or if they did not report any relevant information. Studies were also excluded if they described uncomplicated peptic ulcer, variceal bleeding or other causes of upper gastrointestinal complications. Studies with fewer than 50 patients were excluded for feasibility reasons. Studies in which data collection started before 1990 were also excluded from our analysis of incidence because we aimed to analyze only recent data.

The recurrence rate and 30-day mortality data were synthesized by calculating averages weighted by sample size. The studies varied in their use of odds ratio (OR) and relative risk (RR), and adjusted these measures by different factors; therefore, these have been reported as published rather than synthesized.

\section{Results}

\section{Search Results}

Overall, 93 studies were identified that met the inclusion criteria of the review. Eleven studies reported the incidence of peptic ulcer complications (hemorrhage and perforation) in the general population, 18 reported risk factors for peptic ulcer complications, 30 reported recurrence rates of peptic ulcer complications, 20 reported risk

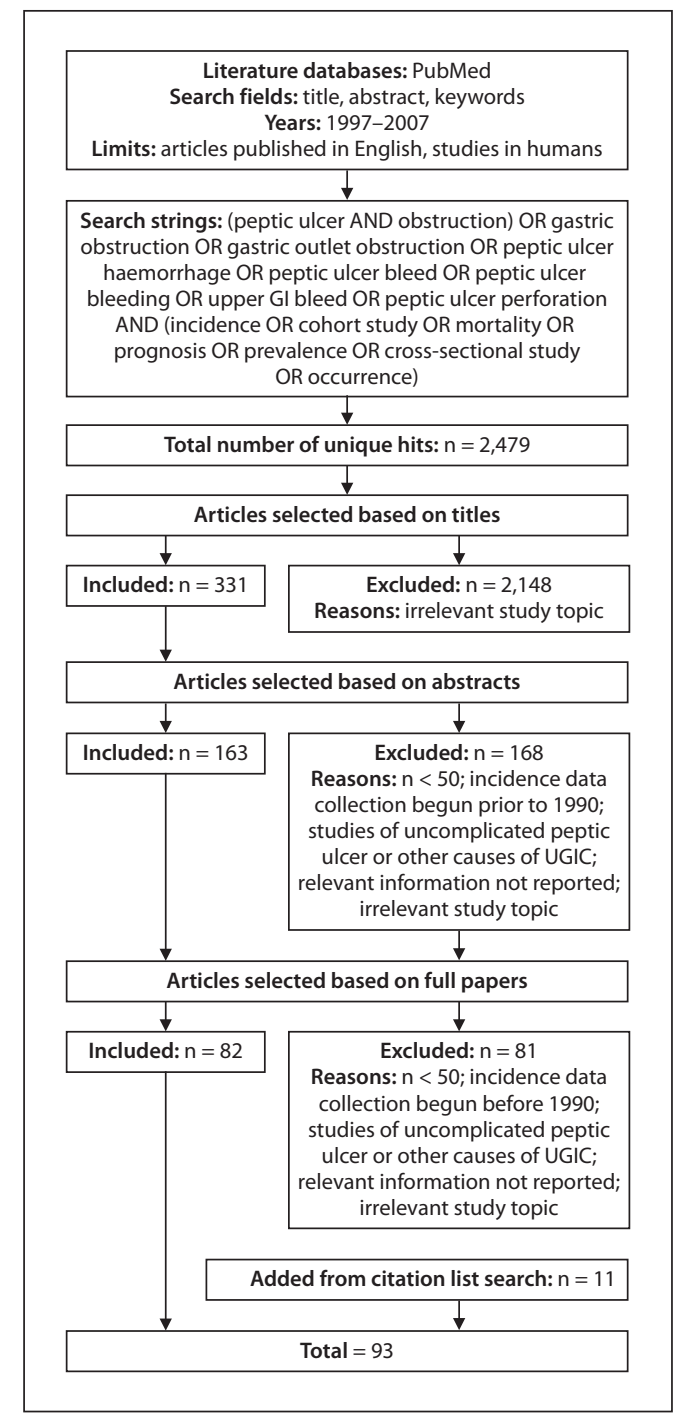

Fig. 1. Flow of prospective studies through the search and selection process. UGIC $=$ Upper gastrointestinal complications.

factors for the recurrence of peptic ulcer complications, 51 reported mortality after peptic ulcer complications and 27 reported risk factors for mortality after peptic ulcer complications (a number of studies reported more than one of these factors).

\section{Incidence of Peptic Ulcer Complications}

Eleven studies, all of which were performed in Europe, reported the incidence of complications associated with peptic ulcer extrapolated to the general population (online suppl. table 1, for all online supplementary material see www.karger.com/doi/10.1159/000323958). Hemorrhage was much more common than perforation [3,9-11]. The 
reported annual incidence of hemorrhage in the general population ranged from 19.4 cases per 100,000 individuals [11] to 57.0 cases per 100,000 individuals [12]. A UK database study reported an annual incidence of 79 cases per 100,000 individuals [13]. However, this study was confined to individuals over 60 years of age, and thus cannot be extrapolated to the population as a whole.

Reported annual incidences of perforation ranged from 3.77 cases per 100,000 individuals [14] to 14 cases per 100,000 individuals [3].

No studies reporting the incidence of gastric obstruction met the inclusion criteria for this review.

\section{Time Trends in Complicated Peptic Ulcer}

The few studies that examined time trends in the incidence of peptic ulcer hemorrhage reported no significant change during the last decade. When comparing 1990-1994 with 1995-2000, Bardhan et al. [11] observed a decrease in the annual incidence of hemorrhage from 21.1 to 19.4 cases per 100,000 individuals in the UK. Van Leerdam et al. [15] reported a similar statistically nonsignificant decrease in the incidence of both gastric ulcer (GU) and duodenal ulcer (DU) hemorrhage between 1993 and 2000. However, Lassen et al. [3] reported a slight nonsignificant increase in the annual incidence of hemorrhage in Denmark from 55 cases per 100,000 in 1993 (95\% CI: 49-62) to 57 cases per 100,000 in 2002 (95\% CI: 51-64).

A study comparing the causes of upper gastrointestinal bleeding among patients admitted to a hospital in Greece between 1986 and 2001 found an increase in the rate of GU (12 vs. $19 \%$; $p=0.005)$ and a concomitant decrease in the rate of DU ( 49 vs. $33 \%$; $p<0.0001$ ) [16].

Two studies noted a decrease in the annual incidence of perforation over time. In Denmark, Lassen et al. [3] reported a significant decrease from 14 cases per 100,000 individuals in 1993 (95\% CI: 11-18) to 8 cases per 100,000 individuals in 2002 (95\% CI: 6-11; $\mathrm{p}=0.01$ ). Bardhan et al. [11] found a decrease in annual incidence in the UK from 9.4 cases per 100,000 individuals during 1990-1994 to 7.9 cases per 100,000 individuals during 1995-2000. The significance of this was not tested.

A study of emergency admissions due to complications of peptic ulcer carried out in Poland between 1996 and 2001 found that the admissions due to hemorrhage and perforation remained relatively constant during this period [17]. There were 52 cases of hemorrhage in 1996, 31 in 1999 and 45 in 2001. There were 18 cases of perforation in 1996, 27 in 1997 and 18 in 2001.
Risk Factors for Complications in Peptic Ulcer Disease

Eighteen studies identified risk factors associated with the initial occurrence of peptic ulcer complications (online suppl. table 2). Most studies examined risk factors for hemorrhage, but two examined risk factors for perforation $[18,19]$, and one included patients with any complication [20]. Prior use of NSAIDs was the most commonly identified risk factor for peptic ulcer hemorrhage (10 studies) [21-30]. The largest increase in risk was found in a prospective study of 96 patients with hemorrhage and 106 control patients with a nonbleeding ulcer in Turkey, which found an OR associated with NSAID use of 33.9 (95\% CI: 4.4-263.0) [26]. In a second prospective study of 227 patients with peptic ulcer hemorrhage in the Netherlands, the RR of bleeding associated with NSAID use was 8.4 (95\% CI: 6.4-10.9) [22].

Lanas et al. [28] performed a case-control study using prospective case ascertainment and retrospective data collection to study 2,777 patients admitted to hospital in Spain because of peptic ulcer bleeding. NSAID use was associated with an increased risk of hemorrhage (RR: 5.3; 95\% CI: 4.5-6.2). This increase in risk was dose-dependent; the RR was 6.8 (95\% CI: 5.3-8.8) with high-dose and 4.0 (95\% CI: 3.2-5.0) with medium- or low-dose NSAIDs. This study also found that current use of ASA increased the risk of hemorrhage (RR: 5.3; 95\% CI: 4.5-6.3). This increase was also dose-dependent; the RR was 2.7 (95\% CI: 2.0-3.6) with $100 \mathrm{mg} /$ day and 7.5 (95\% CI: 5.7-9.9) with $500 \mathrm{mg} /$ day. With the concurrent use of ASA and NSAIDs, the risk was cumulative (RR: 12.7; 95\% CI: 7.023.0).

A retrospective study of 176 patients in Spanish secondary care centers found NSAID use to be the only factor significantly associated with perforation (OR: 3.6; 95\% CI: 1.3-10.0) [19].

Three further European studies examined the association between ASA use and peptic ulcer complications $[21,23,31]$. All three studies used a prospective case-control design, although two studies used patients with no peptic ulcer disease as controls [23,31], while the third used individuals with uncomplicated peptic ulcer [21]. Labenz et al. [31] found that prior use of ASA ( $>100 \mathrm{mg} /$ day) or NSAIDs increased the risk of hemorrhage from GU (OR: 8.1; 95\% CI: 1.2-56.6; $\mathrm{p}=0.034$ ) but not from DU (OR: 1.3; 95\% CI: 0.5-3.8). Santolaria et al. [23] found that use of high-dose ASA ( $>300 \mathrm{mg} /$ day) was associated with an increased risk of both DU (OR: 8.0; 95\% CI: 4.214.9) and GU (OR: 19.7; 95\% CI: 8.6-45.4) bleeding. There was a significant association between low-dose ASA (<300 mg/day) use and hemorrhage from GU (OR: 3.1;
Lau/Sung/Hill/Henderson/Howden/ Metz 
95\% CI: 1.4-6.6) but not with hemorrhage from DU (OR: 1.5; 95\% CI: 0.6-3.9).

Three prospective studies reported an association between $H$. pylori infection and peptic ulcer bleeding [22, 23,31 . The greatest increase in risk was found by Santolaria et al. [23], who reported a RR of 5.98 (95\% CI: 2.912.3 ) in their study of 520 patients in secondary care in Spain. However, a fourth prospective study of 67 patients in Mexico found no association between $H$. pylori infection and hemorrhage [32].

Examination of the relationship between $H$. pylori infection, NSAID use and peptic ulcer complications revealed inconsistent results. In their prospective case-control study, Santolaria et al. [23] found that the combination of NSAID use and H. pylori infection was associated with a significantly reduced risk of GU hemorrhage (OR: 0.19; 95\% CI: 0.04-0.88). A prospective study in Turkey found a similar reduction in the risk of bleeding peptic ulcer associated with NSAID use in $H$. pylori-infected individuals (OR: 0.09; 95\% CI: 0.01-0.83) [26], but this study did not distinguish patients with GU and DU. By contrast, a prospective study in Singapore found that $79 \%$ of GU patients who were $H$. pylori-positive and using NSAIDs presented with bleeding, compared with $20 \%$ of those who were $H$. pylori-negative and not using NSAIDs [25].

Lanas et al. [33] also found $H$. pylori infection to be a risk factor for upper gastrointestinal bleeding in low-dose ASA users in Spain (OR: 4.69; 95\% CI: 2.02-10.91). This increase in risk was found primarily in patients with DU (OR: 8.11; 95\% CI: 2.02-26.93); however, there was also a trend towards an increased risk in patients with GU (OR: 2.74; 95\% CI: 0.98-7.63).

In their prospective study of 119 patients with peptic ulcer in Taiwan, Hsu et al. [24] found patients with an ulcer size of $\geq 1 \mathrm{~cm}$ to be at greater risk of hemorrhage than patients with smaller ulcers (OR: 4.18; 95\% CI: $1.62-$ 10.81).

Prospective studies have found inconsistent results when examining a range of demographic and lifestyle factors. Only one Turkish study [26] found male sex to be a risk factor for hemorrhage (OR: 3.70; 95\% CI: $1.65-$ 8.29). In Singapore, $\mathrm{Ng}$ et al. [25] found that patients aged 65 years and older were at greater risk of peptic ulcer hemorrhage than younger patients (OR: 3.38; 95\% CI: 1.93 5.92), while in Turkey, Okan et al. [26] found an association between older age and peptic ulcer hemorrhage in their univariate, but not in their multivariate, analysis. Hsu et al. [24] found no association between age and peptic ulcer hemorrhage in Taiwan.

Epidemiology of Peptic Ulcer Complications
A large population-based prospective cohort study in Denmark $(n=26,518)$ found that peptic ulcer hemorrhage was significantly associated with the consumption of 28-41 alcoholic drinks per week (RR: 2.8; 95\% CI: 1.45.4) and the consumption of 42 or more alcoholic drinks per week (RR: 4.4; 95\% CI: 2.3-8.3) [18]. However, two further prospective studies in Taiwan and Germany found no association between hemorrhage and alcohol consumption $[21,24]$. Similar patterns were seen with tobacco use. The Danish study reported an association between smoking more than $15 \mathrm{~g}$ of tobacco per day (1 cigarette contains $1 \mathrm{~g}$ of tobacco on average) and the risk of perforated peptic ulcer [18], while the Taiwanese and German studies found no association between smoking and hemorrhage [21, 24].

A case-control study of 2,777 Spanish patients with peptic ulcer hemorrhage found that acid-suppressing drugs have a protective effect against hemorrhage [30]. This study reported that current use of proton pump inhibitors (PPIs; RR: 0.52; 95\% CI: $0.38-0.70$ ) or $\mathrm{H}_{2}$-receptor antagonists (RR: 0.65; 95\% CI: $0.50-0.85$ ) was associated with a reduction in the risk of peptic ulcer hemorrhage. The indications for PPI or $\mathrm{H}_{2}$-receptor antagonist use were not recorded. Current PPI use was associated with an even greater reduction in risk among users of ASA or NSAIDs (RR: 0.13; 95\% CI: 0.04-0.19). This protective effect was apparent against both GU (RR: 0.21; 95\% CI: 0.15-0.29) and DU (RR: 0.15; 95\% CI: 0.10-0.21) hemorrhage. A second, smaller Spanish study $(n=89)$ also found a reduction in the risk of upper gastrointestinal hemorrhage to be associated with PPI use (OR: 0.02; 95\% CI: 0.002-0.26) and, to a lesser extent, $\mathrm{H}_{2}$-receptor antagonist use (OR: 0.16; 95\% CI: 0.05-0.57) [33].

\section{Recurrence of Peptic Ulcer Complications}

Twenty-eight studies reported the recurrence of peptic ulcer hemorrhage (online suppl. table 3). Fourteen of these studies did not report the time frame over which this recurrence took place. Three studies reported a recurrence time of 7 days, four reported a recurrence time between 28 days and 1 month, and the remainder reported varying recurrence times of between 90 days and 76 months.

Hemorrhage recurrence rates ranged from $0 \%$ [34] to $31 \%$ [35]. In the USA, Gralnek et al. [35] observed rebleeding within 30 days in $31 \%$ of 155 patients surviving an initial peptic ulcer hemorrhage. Cheng et al. [36] found a 28 -day recurrence rate of $37.5 \%$ in Taiwanese patients with one or more comorbidities, but only a 5\% recurrence rate in patients without comorbidity. Vergara et al. [34] found no rebleeding in a median follow-up of 27 months

Digestion 2011;84:102-113 
among 103 patients with bleeding DU in Spain who had undergone $H$. pylori eradication treatment. The average recurrence rate ( 28 studies) weighted by sample size was $10.0 \%$ (95\% CI: 6.9-13.1). The average 7-day recurrence rate (3 studies) weighted by sample size was $13.9 \%(95 \%$ CI: 8.4-19.4), whereas the average 1-month recurrence rate (4 studies) weighted by sample size was $15.8 \%$ (95\% CI: 11.0-20.5).

Two studies (performed in the USA and Hong Kong) that reported the rebleeding rate at both 7 and 30 days found that approximately $90 \%$ of recurrent bleeds occurred in the first 7 days $[37,38]$.

Five studies reported the recurrence of peptic ulcer perforation (online suppl. table 3). Only one study reported postoperative reperforation [39]. This Swedish study found an incidence of $0.4 \%$ among 237 patients who had surgical management of ulcer perforation. The remaining studies reported long-term recurrence of up to 20 years. The highest recurrence rate was $24.6 \%$ over 5 years in 130 individuals from Japan who were over 70 years of age [40]. The average long-term recurrence rate (4 studies) weighted by sample size was $12.1 \%$ (95\% CI: 6.3-17.8).

\section{Risk Factors for the Recurrence of Peptic Ulcer Disease Complications}

Twenty studies identified risk factors for the development of further complications in patients with a history of peptic ulcer complications (online suppl. table 4). However, only one retrospective study looked specifically at risk factors for recurrent perforation [41]. One prospective study examined risk factors for the occurrence of any further complication after perforation [42]. The remaining studies assessed risk factors for rebleeding.

Three prospective studies (performed in the USA and the UK) reported that NSAID use increased the risk of rebleeding [43-45]. However, a fourth prospective study set in Sweden found that admission due to ASA or NSAID-associated ulcer bleeding was associated with a significantly lower risk of rebleeding (OR: 0.53 ; 95\% CI: 0.28-0.95) [46], perhaps because ASA or NSAIDs were discontinued after the initial bleed.

Large ulcer size has also been identified as a risk factor for rebleeding. One study in Hong Kong reported an almost fivefold increase in risk associated with ulcers larger than $1 \mathrm{~cm}$ in diameter (OR: 4.69; 95\% CI: 1.6-13.8) [47]. Two further prospective studies, in Korea and Italy, also found an association between ulcer size and rebleeding $[48,49]$.

Examination of the relationship between age and rebleeding has produced inconsistent results. In a pro- spective study of 1,744 patients treated for peptic ulcer bleeding in China, patients over 80 years of age were found to have a significantly increased risk of rebleeding compared with patients younger than 80 years [50]. A second study in the USA found the age of 60 years or older to be associated with a significant increase in the risk of rebleeding (OR: 8.0; 95\% CI: 2.8-22.8) [37]. However, four subsequent studies in Europe and Asia found no association between age and the risk of rebleeding $[46,49,51,52]$.

It is possible that there is a genetic component to peptic ulcer complications. In Korea, Kim et al. [53] observed a potential association between the $4 \mathrm{G} / 4 \mathrm{G}$ genotype of the plasminogen activator inhibitor type 1 and the recurrence of peptic ulcer rebleeding. Other reported risk factors for rebleeding included anticoagulant use [37, 52], shock [46] and low blood pressure [48, 51].

A history of PPI use, however, appears to reduce the risk of rebleeding. A study using the UK General Practice Research Database found that current long-term use of omeprazole was associated with a reduction in the risk of recurrent bleeding (RR: 0.2; 95\% CI: 0.02-1.0) [52]. This reduction in risk was also apparent when the analysis was restricted to those patients who were also taking NSAIDs (RR: 0.0; 95\% CI: 0.0-1.0). Two other studies in Sweden and Taiwan also found that omeprazole use reduced the risk of rebleeding. Hasselgren et al. [46] found omeprazole use to be associated with a $64 \%$ decrease in the risk of rebleeding, while Lin et al. [54] found omeprazole use to be an independent factor for preventing rebleeding (OR: 7.68; 95\% CI: 1.64-35.98).

Only one retrospective study in Australia $(n=147)$ examined risk factors for recurrent perforation [41]. This study found that the presence of malignancy (RR: 4.2; 95\% CI: 1.4-13.0), use of immunosuppressants (RR: 6.3; 95\% CI: 2.1-19.4), use of corticosteroids (RR: 4.4; 95\% CI: 1.5-13.1), presence of shock (RR: 3.4; 95\% CI: 1.1-10.6) and admission to intensive care (RR: 4.7; 95\% CI: 1.614.4) were all associated with an increased risk of recurrent perforation.

\section{Mortality after Peptic Ulcer Complications}

Twenty-six studies reported the mortality associated with peptic ulcer hemorrhage (online suppl. table 5). The 30-day mortality after peptic ulcer hemorrhage ranged from $1.7 \%$ in Scotland [55] to $10.7 \%$ in Denmark [56] (fig. 2a), giving a sample size-weighted average (6 studies) mortality of $8.6 \%$ (95\% CI: 5.8-11.4). Twenty-seven studies reported the mortality associated with peptic ulcer perforation (online suppl. table 6). The 30-day mortality 
Fig. 2. Thirty-day mortality after peptic ulcer: hemorrhage (a) $[37,38,46,55,56,97]$ and perforation (b) $[39,57,58,113]$.
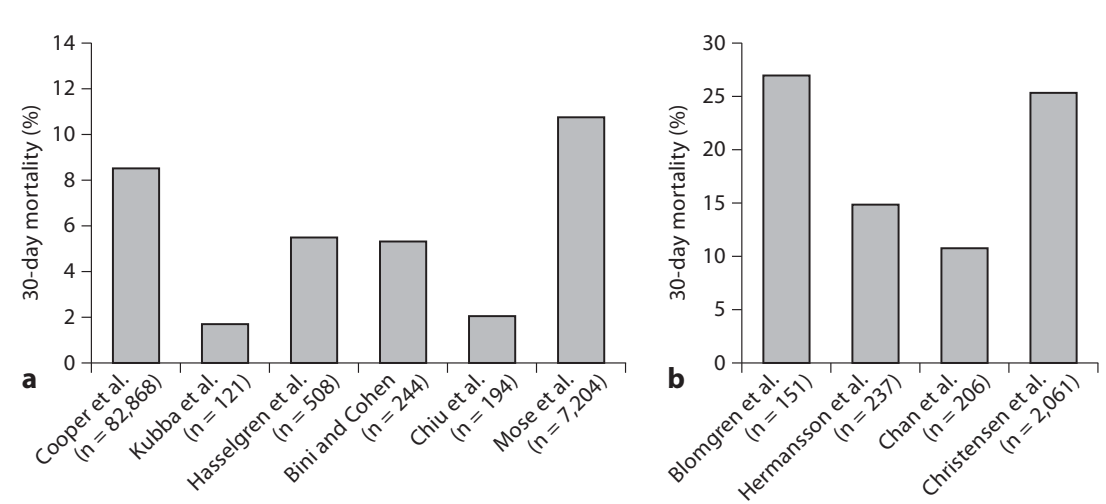

after peptic ulcer perforation ranged from $10.7 \%$ in Singapore [57] to $27.0 \%$ in Sweden [58] (fig. 2b), giving a sample size-weighted average (4 studies) mortality of $23.5 \%$ (95\% CI: 15.5-31.0).

\section{Risk Factors for Mortality in Peptic Ulcer Disease}

The most widely reported risk factor for mortality was increasing age, reported by 14 studies (online suppl. tables 5 and 6) [12, 15, 39, 46, 51, 59-67]. In most cases, this increase in mortality was associated with age over 60 years. A UK database study $(n=1,020)$ examined the association between age and mortality in peptic ulcer patients in more detail [67]. Compared with patients aged $30-59$ years, there was a trend towards an increased mortality risk in patients aged $60-69$ years (OR: 2.8 ; 95\% CI: $0.9-9.1)$. This association reached significance in patients aged $70-79$ years (OR: 4.2; 95\% CI: $1.4-12.7$ ) and increased still further in patients aged $80-89$ years (OR: 6.2; 95\% CI: 2.0-19.1). A prospective secondary care-based study in the Netherlands $(\mathrm{n}=379)$ found an increased risk of mortality in patients aged 58-71 years (OR: 2.47; 95\% CI: 1.11-5.53) and patients aged 72-79 years (OR: 2.10; 95\% CI: 1.02-3.97) when compared with patients aged 7-57 years [15]. However, this study found no significant increase in risk in patients aged $80-99$ years (OR: 0.91; 95\% CI: 0.52-1.57).

Increased age has also been shown to be associated with increased mortality after perforation $[39,59,60,64]$. In a prospective study of 102 patients who underwent surgery for perforated peptic ulcer in Germany, patients aged over 65 years had a significantly worse prognosis than younger patients $(\mathrm{p}<0.05)$ [59]. A retrospective Swedish study of 246 patients with perforation found that mortality after perforation was $0 \%$ in patients aged under
50 years, $6 \%$ in patients aged $50-70$ years and $30 \%$ in patients aged over 70 years $(p<0.0001)$ [39].

The presence of comorbidity is also associated with an increase in mortality after hemorrhage and perforation. In their prospective study in Estonia, Soplepmann et al. [12] found that mortality was significantly increased in patients with peptic ulcer hemorrhage who also had major cardiac disease $(p=0.0001)$. A retrospective study in Denmark also found that, after ulcer bleeding, patients with diabetes had a higher 30-day mortality than patients without diabetes (mortality rate ratio: 1.40; 95\% CI: 1.151.70); this was also apparent after ulcer perforation (mortality rate ratio: 1.51 ; $95 \%$ CI: $1.15-1.98$ ) [68]. Other prospective studies in Europe $[15,69]$ and retrospective studies in Asia [57, 70] have also reported a link between unspecified comorbidities and increased mortality after peptic ulcer hemorrhage or perforation.

Hasselgren et al. [46] found that Swedish patients with a history of peptic ulcer disease had a lower mortality risk after hemorrhage than patients with no previous peptic ulcer disease (OR: 0.26; 95\% CI: 0.09-0.74). García Rodríguez et al. [67] found similar results in the UK, in that patients with no previously recorded peptic ulcer disease had a higher mortality risk after hemorrhage than patients with previously recorded peptic ulcer disease (RR: 3.0; $95 \%$ CI: 1.2-7.1).

Shock is another major risk factor for increased mortality after both hemorrhage and perforation. In Portugal, Noguiera et al. [69] found that shock was associated with a sevenfold increase in mortality in patients with peptic ulcer hemorrhage (OR: 7.26; 95\% CI: 1.53-34.52). Five further studies in Europe, Asia and Africa also reported increased mortality associated with shock in patients with hemorrhage [12] or perforation $[57,60-62,71]$. 
Table 1. Factors associated with the occurrence and recurrence of peptic ulcer complications and with mortality after peptic ulcer complications

\begin{tabular}{|c|c|c|c|}
\hline Risk factor & Occurrence & Recurrence & Mortality \\
\hline Male sex & $\checkmark$ & & \\
\hline Increasing age & $\checkmark$ & $\checkmark$ & $\checkmark$ \\
\hline Serious comorbidity & $\checkmark$ & $\checkmark$ & $\checkmark$ \\
\hline PAI-1 4G/4G genotype & & $\checkmark$ & \\
\hline Tertiary education & $\checkmark$ & & \\
\hline High alcohol use & $\checkmark$ & & \\
\hline Smoking & $\checkmark$ & & \\
\hline NSAID use & $\checkmark$ & $\checkmark$ & \\
\hline ASA use & $\checkmark$ & $\checkmark$ & \\
\hline High-dose & $\checkmark$ & & \\
\hline Low-dose & $\checkmark$ & & \\
\hline Anticoagulant use & & $\checkmark$ & \\
\hline Immunosuppressant use & & $\checkmark$ & \\
\hline Corticosteroid use & & $\checkmark$ & $\checkmark$ \\
\hline Shock & & $\checkmark$ & $\checkmark$ \\
\hline Low hemoglobin levels at initial presentation & & $\checkmark$ & $\checkmark$ \\
\hline Low blood pressure & & $\checkmark$ & $\checkmark$ \\
\hline Treatment delay & & & $\checkmark$ \\
\hline H. pylori infection & $\checkmark$ & $\checkmark$ & \\
\hline History of peptic ulcer & $\checkmark$ & & \\
\hline No history of peptic ulcer & & & $\checkmark$ \\
\hline Large ulcer size $(>1 \mathrm{~cm})$ & $\checkmark$ & $\checkmark$ & \\
\hline Forrest class I-II & & $\checkmark$ & $\checkmark$ \\
\hline Recurrence of complication & & & $\checkmark$ \\
\hline
\end{tabular}

However, three studies (performed in Sweden, Estonia and Taiwan) found no association between shock and mortality $[64,66,70]$. One retrospective study in Saudi Arabia found an increase in mortality after hemorrhage in patients with low systolic blood pressure (OR: 7.44; 95\% CI: 1.01-54.55) [51].

Delayed treatment is also associated with an increase in the risk of mortality in patients with peptic ulcer perforation. In their prospective study in India, Rajesh et al. [60] found an increased risk of death if surgery for perforation was delayed for more than $24 \mathrm{~h}$ [RR: 1.75; $\mathrm{p}=0.004$ (this study did not report a confidence interval)]. In a retrospective study in Taiwan, Chou et al. [70] also reported an increased risk of death in patients whose surgery for perforation was delayed.

In a study of the UK General Practice Research Database, García Rodríguez et al. [67] found that current NSAID use was associated with a nonsignificant increase in mortality in patients with peptic ulcer hemorrhage (RR: 2.0; 95\% CI: 1.0-3.8). Three further studies in Estonia, Portugal and Taiwan found no association between
NSAID use and mortality in patients with peptic ulcer hemorrhage [12] or perforation [69, 70]. In Denmark, Mose et al. [56] found that individuals with peptic ulcer bleeding who were current users of low-dose ASA had an adjusted mortality ratio of 0.83 (95\% CI: $0.68-1.01$ ) when compared with those individuals who had never used low-dose ASA.

\section{Discussion}

The prevalence of peptic ulcer has fallen in recent years $[1,2,72]$. Despite this and recent advances in ulcer treatment, complications remain a substantial healthcare problem. This may be due to an increase in the use of ASA and NSAIDs and to the increasing number of elderly people in many countries.

Our review of recently published studies found annual incidences of ulcer hemorrhage and perforation of 19.4-57.0 and 3.8-14 cases per 100,000 individuals, respectively. These complications are more common with 
increasing age $[13,73]$. Several risk factors for peptic ulcer complications are also associated with an increase in recurrence and mortality (table 1). The widespread use of ASA and NSAIDs probably contributes substantially to the burden of complicated peptic ulcer [6]. Use of ASA (even at low doses) or NSAIDs was the most commonly reported risk factor for DU and GU hemorrhage in the studies that we identified $[23,28]$.

The effects have been inconsistent when the relationship between $H$. pylori infection, NSAID use and peptic ulcer complications have been assessed. Two studies found a reduced risk of GU complications among $H$. $p y$ lori-infected patients taking ASA or NSAIDs [23, 26]. This could be because $H$. pylori induces an increase in gastric mucosal prostaglandin $\mathrm{E}_{2}$ levels that may partially reverse the mucosal toxicity of ASA or NSAIDs [7476]. H. pylori infection may suppress gastric acid secretion in some individuals [77]. However, other studies have reported an increase in the risk of rebleeding when both $H$. pylori infection and ASA/NSAID use were present $[25,33]$. A meta-analysis looking specifically at this issue found an additive effect between $H$. pylori infection and NSAID use [78]. When H. pylori infection and NSAID use were present together, the risk of bleeding was higher than when the risk factors were present on their own.

Risk factors for complicated peptic ulcer may be different in Asian and Western countries. Increasing age and large ulcer size were associated with a significant increase in the risk of complicated peptic ulcer only in Asia, and serious comorbidity was associated with a significant increase in risk only in Western countries. However, not all studies examined these risk factors, so this may simply reflect differences in study methodology.

Up to $31 \%$ of patients with peptic ulcer hemorrhage experience rebleeding within 30 days. Mortality is high among patients with complicated peptic ulcer, especially after perforation. Mortality increases with age, which probably reflects an increased prevalence of comorbidities [79].

Patients with no previous diagnosis of peptic ulcer may have a higher risk of dying than patients with a known history of ulcer disease [46, 67]. This may be because preventative measures are more likely to have been taken in patients with a known history of ulcer (e.g. $H$. pylori eradication, PPI therapy, avoidance of ASA and NSAIDs). Furthermore, these patients are perhaps more likely to seek treatment earlier.

Despite the fact that ASA and/or NSAID use are risk factors for recurrent bleeding and recurrent bleeding is a risk factor for death, mortality after peptic ulcer complications appears to be the same whether or not patients take ASA or NSAIDs. Again, this suggests that a large proportion of the deaths that occur after hemorrhage or perforation is due to comorbid disease rather than the event itself.

Patients with prior complicated ulcers should have their risk factors eliminated wherever possible. This includes the eradication of $H$. pylori and cessation of ASA or NSAID treatment whenever appropriate. Patients with $H$. pylori-negative idiopathic ulcers and those who require continuation of ASA or NSAID treatment should receive maintenance PPI therapy. Prompt management of perforated peptic ulcer should decrease mortality.

This is the first systematic review of the epidemiology of complicated peptic ulcer disease. A key strength of the review is the wide range of studies with varying methodologies that were identified, analysis of which is likely to give an accurate picture of clinical practice. However, one limitation was the lack of detail reported in some studies. Many of the studies failed to distinguish between GU and DU. This made it difficult to analyze any potential differences between the two in terms of risk factors and recurrence. We excluded studies that were published before 1997 and, from our examination of incidence, those that began data collection before 1990. This may have led to the underestimation of some results. However, it does ensure that we have focused on the most current picture possible. Most data on risk factors come from case-control studies in which the risk estimate is highly dependent on the group of individuals chosen for comparison. Incidence is based on extrapolating data from secondary care to the general population as a whole. This process could cause some cases to be missed, and individuals who died before they could be admitted to hospital would perhaps not be counted. This could again lead to underestimation of the results.

Another limitation is the lack of incidence data from outside Europe. In this respect, our findings may therefore not be fully representative of the situation in the rest of the world. However, the data on recurrence and mortality do come from a wide variety of locations in Asia and Africa as well as Western countries, which provides support for the validity of our results.

Our analysis suggests that there may be different risk factors for GU and DU complications. It would be interesting to carry out more studies to clarify this. It would also be useful to perform studies examining temporal trends in the incidence and prevalence of complicated peptic ulcer in order to gain a fuller understanding of the 
epidemiology of this disease, and to help plan for future healthcare needs.

In conclusion, peptic ulcer complications remain a substantial healthcare problem, which is likely to be due to the widespread use of ASA and NSAIDs. This widespread use of NSAIDs may also increase the risk of recurrent complications. Mortality after peptic ulcer complications increases with age, which is probably caused by an age-related increase in comorbidity. However, mortality does not appear to be affected by the use of ASA or NSAIDs. Swift diagnosis and treatment of complicated peptic ulcer is likely to decrease mortality. Use of a PPI may help to reduce the risk of peptic ulcer complications, and may also reduce the risk of rebleeding in patients with a history of peptic ulcer hemorrhage.

\section{Disclosure Statement}

The writing of this paper was funded in part by AstraZeneca R\&D Mölndal. James Y. Lau has served as a speaker, consultant and advisory board member for AstraZeneca. Joseph Sung has served as a speaker and advisory board member for AstraZeneca, and as a speaker for Nycomed. Catherine Hill is an employee of Oxford PharmaGenesis ${ }^{\mathrm{TM}}$ Limited, which has received project funding from AstraZeneca. Catherine Henderson was an employee of Oxford PharmaGenesis ${ }^{\mathrm{TM}}$ Limited at the time the study was conducted. Colin W. Howden has served as a speaker, consultant and advisory board member for TAP, Takeda Pharmaceuticals North America, Santarus, AstraZeneca, Novartis, Novartis Consumer Health, Meretek, Otsuka, Biovail, Extera Partners, Depomed, Apotex and KV Pharmaceuticals, and has received research funding from AstraZeneca. David C. Metz has served as a speaker for AstraZeneca, Takeda (formerly TAP Pharmaceuticals), Santarus and Wyeth; as a consultant for AstraZeneca, Takeda, Nycomed (formerly Byk Gulden), Santarus and Wyeth, as an advisory board member for AstraZeneca, Takeda, Santarus and Wyeth, and has received grant support from AstraZeneca, Takeda and Wyeth.

\section{References}

$>_{1}$ Xia B, Xia HH, Ma CW, Wong KW, Fung FM, Hui CK, Chan CK, Chan AO, Lai KC, Yuen MF, Wong BC: Trends in the prevalence of peptic ulcer disease and Helicobacter pylori infection in family physician-referred uninvestigated dyspeptic patients in Hong Kong. Aliment Pharmacol Ther 2005;22:243-249.

2 Wong SN, Sollano JD, Chan MM, Carpio RE, Tady CS, Ismael AE, Judan-Ruiz EA, Ang VN, Go JT, Lim VY, Perez JY, Alvarez SZ: Changing trends in peptic ulcer prevalence in a tertiary care setting in the Philippines: a seven-year study. J Gastroenterol Hepatol 2005;20:628-632.

-3 Lassen A, Hallas J, Schaffalitzky de Muckadell OB: Complicated and uncomplicated peptic ulcers in a Danish county 1993-2002: a population-based cohort study. Am J Gastroenterol 2006;101:945-953.

4 Everhart JE: Recent developments in the epidemiology of Helicobacter pylori. Gastroenterol Clin North Am 2000;29:559-578.

5 McCarthy DM: Prevention and treatment of gastrointestinal symptoms and complications due to NSAIDs. Best Pract Res Clin Gastroenterol 2001;15:755-773.

-6 Schiffmann L, Kahrau S, Berger G, Buhr HJ: Colon perforation in an adolescent after short-term diclofenac intake. ANZ J Surg 2005;75:726-727.

7 Sonnenberg A, Everhart JE: Health impact of peptic ulcer in the United States. Am J Gastroenterol 1997;92:614-620.

$\checkmark 8$ de Leest H, van Dieten H, van Tulder M, Lems WF, Dijkmans BA, Boers M: Costs of treating bleeding and perforated peptic ulcers in the Netherlands. J Rheumatol 2004; 31:788-791.
9 Higham J, Kang JY, Majeed A: Recent trends in admissions and mortality due to peptic ulcer in England: increasing frequency of haemorrhage among older subjects. Gut 2002;50:460-464.

10 Paimela H, Paimela L, Myllykangas-Luosujarvi R, Kivilaakso E: Current features of peptic ulcer disease in Finland: incidence of surgery, hospital admissions and mortality for the disease during the past twenty-five years. Scand J Gastroenterol 2002;37:399_ 403.

11 Bardhan KD, Williamson M, Royston C, Lyon C: Admission rates for peptic ulcer in the Trent region, UK, 1972-2000. Changing pattern, a changing disease? Dig Liver Dis 2004;36:577-588.

12 Soplepmann J, Peetsalu A, Peetsalu M, Tein A, Juhola M: Peptic ulcer haemorrhage in Tartu County, Estonia: epidemiology and mortality risk factors. Scand J Gastroenterol 1997;32:1195-1200.

13 Langman MJ: Ulcer complications associated with anti-inflammatory drug use. What is the extent of the disease burden? Pharmacoepidemiol Drug Saf 2001;10:13-19.

14 Canoy DS, Hart AR, Todd CJ: Epidemiology of duodenal ulcer perforation: a study on hospital admissions in Norfolk, United Kingdom. Dig Liver Dis 2002;34:322-327.

15 van Leerdam ME, Vreeburg EM, Rauws EA, Geraedts AA, Tijssen JG, Reitsma JB, Tytgat GN: Acute upper GI bleeding: did anything change? Time trend analysis of incidence and outcome of acute upper GI bleeding between 1993/1994 and 2000. Am J Gastroenterol 2003;98:1494-1499.
16 Thomopoulos KC, Vagenas KA, Vagianos CE, Margaritis VG, Blikas AP, Katsakoulis EC, Nikolopoulou VN: Changes in aetiology and clinical outcome of acute upper gastrointestinal bleeding during the last 15 years. Eur J Gastroenterol Hepatol 2004; 16:177182 .

17 Bobrzynski A, Beben P, Budzynski A, Bielanski W, Plonka M, Konturek S: Incidence of complications of peptic ulcers in patients with Helicobacter pylori $(\mathrm{Hp})$ infection and/ or NSAID use in the era of $\mathrm{Hp}$ eradication. Med Sci Monit 2002;8:CR554-CR557.

18 Andersen IB, Jorgensen T, Bonnevie O, Gronbaek M, Sorensen TI: Smoking and alcohol intake as risk factors for bleeding and perforated peptic ulcers: a population-based cohort study. Epidemiology 2000;11:434439.

19 Gisbert JP, Legido J, Garcia-Sanz I, Pajares JM: Helicobacter pylori and perforated peptic ulcer prevalence of the infection and role of non-steroidal anti-inflammatory drugs. Dig Liver Dis 2004;36:116-120.

-20 Schnitzer TJ, Burmester GR, Mysler E, Hochberg MC, Doherty M, Ehrsam E, Gitton X, Krammer G, Mellein B, Matchaba P, Gimona A, Hawkey CJ: Comparison of lumiracoxib with naproxen and ibuprofen in the Therapeutic Arthritis Research and Gastrointestinal Event Trial (TARGET), reduction in ulcer complications: randomised controlled trial. Lancet 2004;364:665-674.

21 Imhof M, Ohmann C, Hartwig A, Thon KP, Hengels KJ, Roher HD: Which peptic ulcers bleed? Results of a case-control study. Scand J Gastroenterol 1997;32:131-138. 
-22 Kuyvenhoven JP, Veenendaal RA, Vandenbroucke JP: Peptic ulcer bleeding: interaction between non-steroidal anti-inflammatory drugs, Helicobacter pylori infection, and the ABO blood group system. Scand J Gastroenterol 1999;34:1082-1086.

-23 Santolaria S, Lanas A, Benito R, Perez-Aisa M, Montoro M, Sainz R: Helicobacter pylori infection is a protective factor for bleeding gastric ulcers but not for bleeding duodenal ulcers in NSAID users. Aliment Pharmacol Ther 1999;13:1511-1518.

-24 Hsu PI, Lai KH, Tseng HH, Lin CK, Lo GH, Cheng JS, Chan HH, Chen GC, Jou HS, Peng NJ, Ger LP, Chen W, Hsu PN: Risk factors for presentation with bleeding in patients with Helicobacter pylori-related peptic ulcer diseases. J Clin Gastroenterol 2000;30:386-391.

-25 Ng TM, Fock KM, Khor JL, Teo EK, Sim CS, Tan AL, Machin D: Non-steroidal anti-inflammatory drugs, Helicobacter pylori and bleeding gastric ulcer. Aliment Pharmacol Ther 2000;14:203-209.

-26 Okan A, Tankurt E, Aslan BU, Akpinar H, Simsek I, Gonen O: Relationship between non-steroidal anti-inflammatory drug use and Helicobacter pylori infection in bleeding or uncomplicated peptic ulcers: a case-control study. J Gastroenterol Hepatol 2003;18:18-25.

-27 Gisbert JP, Gonzalez L, de Pedro A, Valbuena M, Prieto B, Llorca I, Briz R, Khorrami S, Garcia-Gravalos R, Pajares JM: Helicobacter pylori and bleeding duodenal ulcer: prevalence of the infection and role of non-steroidal anti-inflammatory drugs. Scand J Gastroenterol 2001;36:717-724.

-28 Lanas A, García Rodríguez LA, Arroyo MT, Gomollón F, Feu F, González-Pérez A, Zapata E, Bástida G, Rodrigo L, Santolaria S, Güell M, de Argila CM, Quintero E, Borda F, Piqué JM: Risk of upper gastrointestinal ulcer bleeding associated with selective cyclo-oxygenase-2 inhibitors, traditional nonaspirin non-steroidal anti-inflammatory drugs, aspirin and combinations. Gut 2006; 55:1731-1738.

-29 Zapata-Colindres JC, Zepeda-Gomez S, Montano-Loza A, Vazquez-Ballesteros E, de Jesus Villalobos J, Valdovinos-Andraca F: The association of Helicobacter pylori infection and nonsteroidal anti-inflammatory drugs in peptic ulcer disease. Can J Gastroenterol 2006;20:277-280.

-30 Lanas A, García Rodríguez LA, Arroyo MT, Bujanda L, Gomollón F, Forné M, Aleman S, Nicolas D, Feu F, González-Pérez A, Borda A, Castro M, Poveda MJ, Arenas J: Effect of antisecretory drugs and nitrates on the risk of ulcer bleeding associated with nonsteroidal anti-inflammatory drugs, antiplatelet agents, and anticoagulants. Am J Gastroenterol 2007;102:507-515.

-31 Labenz J, Peitz U, Köhl H, Kaiser J, Malfertheiner P, Hackelsberger A, Börsch G: Helicobacter pylori increases the risk of peptic ulcer bleeding: a case-control study. Ital J Gastroenterol Hepatol 1999;31:110-115.
32 Castillo-Rojas G, Ballesteros MA, Ponce de León S, Morales-Espinosa R, Cravioto A, López-Vidal Y: Bleeding peptic ulcers and presence of Helicobacter pylori by various tests: a case-control study. Eur J Gastroenterol Hepatol 2002;14:1113-1118.

33 Lanas A, Fuentes J, Benito R, Serrano P, Bajador E, Sainz R: Helicobacter pylori increases the risk of upper gastrointestinal bleeding in patients taking low-dose aspirin. Aliment Pharmacol Ther 2002;16:779-786.

34 Vergara M, Casellas F, Saperas E, de Torres I, Lopez J, Borruel N, Armengol JR, Malagelada JR: Helicobacter pylori eradication prevents recurrence from peptic ulcer haemorrhage. Eur J Gastroenterol Hepatol 2000;12: 733-737.

35 Gralnek IM, Jensen DM, Gornbein J, Kovacs TO, Jutabha R, Freeman ML, King J, Jensen ME, Cheng S, Machicado GA, Smith JA, Randall GM, Sue M: Clinical and economic outcomes of individuals with severe peptic ulcer hemorrhage and nonbleeding visible vessel: an analysis of two prospective clinical trials. Am J Gastroenterol 1998;93:20472056.

36 Cheng HC, Chuang SA, Kao YH, Kao AW, Chuang $\mathrm{CH}$, Sheu BS: Increased risk of rebleeding of peptic ulcer bleeding in patients with comorbid illness receiving omeprazole infusion. Hepatogastroenterology 2003;50: 2270-2273.

37 Bini EJ, Cohen J: Endoscopic treatment compared with medical therapy for the prevention of recurrent ulcer hemorrhage in patients with adherent clots. Gastrointest Endosc 2003;58:707-714.

38 Chiu PW, Lam CY, Lee SW, Kwong KH, Lam SH, Lee DT, Kwok SP: Effect of scheduled second therapeutic endoscopy on peptic ulcer rebleeding: a prospective randomised trial. Gut 2003;52:1403-1407.

39 Hermansson M, Stael von Holstein C, Zilling T: Peptic ulcer perforation before and after the introduction of H2-receptor blockers and proton pump inhibitors. Scand J Gastroenterol 1997;32:523-529.

40 Tsugawa K, Koyanagi N, Hashizume M, Tomikawa M, Akahoshi K, Ayukawa K, Wada H, Tanoue K, Sugimachi K: The therapeutic strategies in performing emergency surgery for gastroduodenal ulcer perforation in 130 patients over 70 years of age. Hepatogastroenterology 2001;48:156-162.

41 Evans JP, Smith R: Predicting poor outcome in perforated peptic ulcer disease. ANZ J Surg 1997;67:792-795.

42 Sharma SS, Mamtani MR, Sharma MS, Kulkarni H: A prospective cohort study of postoperative complications in the management of perforated peptic ulcer. BMC Surg 2006;6:8.

43 Cebollero-Santamaria F, Smith J, Gioe S, Van Frank T, Mc Call R, Airhart J, Perrillo R: Selective outpatient management of upper gastrointestinal bleeding in the elderly. Am J Gastroenterol 1999;94:1242-1247.
44 Godil A, DeGuzman L, Schilling RC 3rd, Khan SA, Chen YK: Recent nonsteroidal anti-inflammatory drug use increases the risk of early recurrence of bleeding in patients presenting with bleeding ulcer. Gastrointest Endosc 2000;51:146-151.

-45 García Rodríguez LA, Hernández-Díaz S: Risk of uncomplicated peptic ulcer among users of aspirin and nonaspirin nonsteroidal antiinflammatory drugs. Am J Epidemiol 2004;159:23-31.

-46 Hasselgren G, Carlsson J, Lind T, Schaffalitzky de Muckadell O, Lundell L: Risk factors for rebleeding and fatal outcome in elderly patients with acute peptic ulcer bleeding. Eur J Gastroenterol Hepatol 1998;10:667-672.

$\checkmark 47$ Chiu PW, Joeng HK, Choi CL, Kwong KH, $\mathrm{Ng}$ EK, Lam SH: Predictors of peptic ulcer rebleeding after scheduled second endoscopy: clinical or endoscopic factors? Endoscopy 2006;38:726-729.

48 Guglielmi A, Ruzzenente A, Sandri M, Kind R, Lombardo F, Rodella L, Catalano F, de Manzoni G, Cordiano C: Risk assessment and prediction of rebleeding in bleeding gastroduodenal ulcer. Endoscopy 2002;34:778786.

49 Chung IK, Kim EJ, Lee MS, Kim HS, Park $\mathrm{SH}$, Lee MH, Kim SJ, Cho MS, Hwang KY: Endoscopic factors predisposing to rebleeding following endoscopic hemostasis in bleeding peptic ulcers. Endoscopy 2001;33: 969-975.

50 Chow LW, Gertsch P, Poon RT, Branicki FJ: Risk factors for rebleeding and death from peptic ulcer in the very elderly. Br J Surg 1998;85:121-124.

51 Al-Akeely MH, Alam MK, Al-Salamah SM, Abdu MA, Al-Teimi IN, Mohammed AA: Initial factors predicting rebleeding and death in bleeding peptic ulcer disease. Saudi Med J 2004;25:642-647.

52 García Rodríguez LA, Ruigómez A: Secondary prevention of upper gastrointestinal bleeding associated with maintenance acidsuppressing treatment in patients with peptic ulcer bleed. Epidemiology 1999;10:228232.

53 Kim HS, Hwang KY, Chung IK, Park SH, Lee MH, Kim SJ, Hong SY: Tissue plasminogen activator and plasminogen activator inhibitor type 1 gene polymorphism in patients with gastric ulcer complicated with bleeding. J Korean Med Sci 2003;18:58-64.

54 Lin HJ, Tseng GY, Lo WC, Lee FY, Perng CL, Chang FY, Lee SD: Predictive factors for rebleeding in patients with peptic ulcer bleeding after multipolar electrocoagulation: a retrospective analysis. J Clin Gastroenterol 1998;26:113-116.

55 Kubba AK, Choudari C, Rajgopal C, Ghosh S, Palmer KR: Reduced long-term survival following major peptic ulcer haemorrhage. Br J Surg 1997;84:265-268. 
-56 Mose H, Larsen M, Riis A, Johnsen SP, Thomsen RW, Sorensen HT: Thirty-day mortality after peptic ulcer bleeding in hospitalized patients receiving low-dose aspirin at time of admission. Am J Geriatr Pharmacother 2006;4:244-250.

-57 Chan WH, Wong WK, Khin LW, Soo KC: Adverse operative risk factors for perforated peptic ulcer. Ann Acad Med Singapore 2000; 29:164-167.

58 Blomgren LG: Perforated peptic ulcer: longterm results after simple closure in the elderly. World J Surg 1997;21:412-415.

-59 Kujath P, Schwandner O, Bruch HP: Morbidity and mortality of perforated peptic gastroduodenal ulcer following emergency surgery. Langenbecks Arch Surg 2002;387:298302.

60 Rajesh V, Chandra SS, Smile SR: Risk factors predicting operative mortality in perforated peptic ulcer disease. Trop Gastroenterol 2003; 24:148-150.

61 Kocer B, Surmeli S, Solak C, Unal B, Bozkurt B, Yildirim O, Dolapci M, Cengiz O: Factors affecting mortality and morbidity in patients with peptic ulcer perforation. J Gastroenterol Hepatol 2007;22:565-570.

-62 Deus Fombellida J, Gil Romea I, Moreno Mirallas MJ, Urieta Carpi A: Risk factors in the surgical management of perforated duodeno-pyloric ulcer. Rev Esp Enferm Dig 1998; 90:503-513.

63 Imhof M, Schroders C, Ohmann C, Roher H: Impact of early operation on the mortality from bleeding peptic ulcer - ten years' experience. Dig Surg 1998;15:308-314.

64 Sillakivi T, Lang A, Tein A, Peetsalu A: Evaluation of risk factors for mortality in surgically treated perforated peptic ulcer. Hepatogastroenterology 2000;47:1765-1768.

-65 Imhof M, Epstein S, Ohmann C, Roher HD: Poor late prognosis of bleeding peptic ulcer. Langenbecks Arch Surg 2007;392:587-591.

-66 Hasselgren G, Blomqvist A, Eriksson S, Henningsson A, Lundell L: Short and long term course of elderly patients with peptic ulcer bleeding - analysis of factors influencing fatal outcome. Eur J Surg 1998;164:685-691.

-67 García Rodríguez LA, Ruigómez A, Hasselgren G, Wallander MA, Johansson S: Comparison of mortality from peptic ulcer bleed between patients with or without peptic ulcer antecedents. Epidemiology 1998;9:452456.

68 Thomsen RW, Riis A, Christensen S, Norgaard M, Sorensen HT: Diabetes and 30-day mortality from peptic ulcer bleeding and perforation: a Danish population-based cohort study. Diabetes Care 2006;29:805-810.

-69 Noguiera C, Silva AS, Santos JN, Silva AG, Ferreira J, Matos E, Vilaca H: Perforated peptic ulcer: main factors of morbidity and mortality. World J Surg 2003;27:782-787.

$\checkmark 70$ Chou NH, Mok KT, Chang HT, Liu SI, Tsai CC, Wang BW, Chen IS: Risk factors of mortality in perforated peptic ulcer. Eur J Surg 2000;166:149-153.
71 Madiba TE, Nair R, Mulaudzi TV, Thomson SR: Perforated gastric ulcer - reappraisal of surgical options. S Afr J Surg 2005;43:58-60.

72 Kang JY, Tinto A, Higham J, Majeed A: Peptic ulceration in general practice in England and Wales 1994-98: period prevalence and drug management. Aliment Pharmacol Ther 2002;16:1067-1074.

73 Singh G, Triadafilopoulos G: Epidemiology of NSAID-induced gastrointestinal complications. J Rheumatol Suppl 1999;56:18-24.

74 Hudson N, Balsitis M, Filipowicz F, Hawkey CJ: Effect of Helicobacter pylori colonisation on gastric mucosal eicosanoid synthesis in patients taking non-steroidal anti-inflammatory drugs. Gut 1993;34:748-751.

75 Konturek JW, Dembinski A, Konturek SJ, Stachura J, Domschke W: Infection of Helicobacter pylori in gastric adaptation to continued administration of aspirin in humans. Gastroenterology 1998;114:245-255.

76 Laine L, Cominelli F, Sloane R, Casini-Raggi V, Marin-Sorensen M, Weinstein WM: Interaction of NSAIDs and Helicobacter pylori on gastrointestinal injury and prostaglandin production: a controlled double-blind trial. Aliment Pharmacol Ther 1995;9:127-135.

-77 El-Omar EM, Oien K, El-Nujumi A, Gillen D, Wirz A, Dahill S, Williams C, Ardill JE, McColl KE: Helicobacter pylori infection and chronic gastric acid hyposecretion. Gastroenterology 1997;113:15-24.

78 Huang JQ, Sridhar S, Hunt RH: Role of Helicobacter pylori infection and non-steroidal anti-inflammatory drugs in peptic-ulcer disease: a meta-analysis. Lancet 2002;359: 14-22.

79 Cappell MS: A study of the syndrome of simultaneous acute upper gastrointestinal bleeding and myocardial infarction in $36 \mathrm{pa}-$ tients. Am J Gastroenterol 1995;90:14441449.

80 Ohmann C, Imhof M, Ruppert C, Janzik U, Vogt C, Frieling T, Becker K, Neumann F, Faust S, Heiler K, Haas K, Jurisch R, Wenzel EG, Normann S, Bachmann O, Delgadillo J, Seidel F, Franke C, Luthen R, Yang Q, Reinhold C: Time-trends in the epidemiology of peptic ulcer bleeding. Scand J Gastroenterol 2005;40:914-920.

81 Ramsoekh D, van Leerdam ME, Rauws EA, Tytgat GN: Outcome of peptic ulcer bleeding, nonsteroidal anti-inflammatory drug use, and Helicobacter pylori infection. Clin Gastroenterol Hepatol 2005;3:859-864.

82 Kang JY, Elders A, Majeed A, Maxwell JD, Bardhan KD: Recent trends in hospital admissions and mortality rates for peptic ulcer in Scotland 1982-2002. Aliment Pharmacol Ther 2006;24:65-79.

83 Smalley WE, Ray WA, Daugherty JR, Griffin MR: No association between calcium channel blocker use and confirmed bleeding peptic ulcer disease. Am J Epidemiol 1998;148. 350-354.
84 Klatsky AL, Tekawa I: Health problems and hospitalizations among Asian-American ethnic groups. Ethn Dis 2005; 15:753-760.

$85 \mathrm{Ng} \mathrm{W}$, Wong WM, Chen WH, Tse HF, Lee PY, Lai KC, Li SW, Ng M, Lam KF, Cheng X, Lau CP: Incidence and predictors of upper gastrointestinal bleeding in patients receiving low-dose aspirin for secondary prevention of cardiovascular events in patients with coronary artery disease. World J Gastroenterol 2006;12:2923-2927.

86 Lin HJ, Lo WC, Perng CL, Wang K, Lee FY: Can optimal acid suppression prevent rebleeding in peptic ulcer patients with a nonbleeding visible vessel: a preliminary report of a randomized comparative study. Hepatogastroenterology 1997;44:1495-1499.

87 Bardhan KD, Nayyar AK, Royston C: The outcome of bleeding duodenal ulcer in the era of $\mathrm{H} 2$ receptor antagonist therapy. QJM 1998;91:231-237.

$>88$ Garrigan K, McIntosh C, Fraser AG: Bleeding peptic ulcers: audit of eradication treatment for H pylori. N Z Med J 1999;112:178180 .

89 Lai KC, Hui WM, Wong WM, Wong BC, Hu WH, Ching CK, Lam SK: Treatment of Helicobacter pylori in patients with duodenal ulcer hemorrhage - a long-term randomized, controlled study. Am J Gastroenterol 2000; 95:2225-2232.

90 Segal F, Prolla JC, Maguilnik I, Wolff FH: Clinical and endoscopic aspects in the evolution of patients with bleeding peptic ulcer - a cohort study. Arq Gastroenterol 2000;37: 162-167.

-91 Lanas A, Rodrigo L, Marquez JL, Bajador E, Perez-Roldan F, Cabrol J, Quintero E, Montoro M, Gomollón F, Santolaria S, Lorente S, Cucala M, Nuevo J: Low frequency of upper gastrointestinal complications in a cohort of high-risk patients taking low-dose aspirin or NSAIDS and omeprazole. Scand J Gastroenterol 2003;38:693-700.

92 Testini M, Portincasa P, Piccinni G, Lissidini G, Pellegrini F, Greco L: Significant factors associated with fatal outcome in emergency open surgery for perforated peptic ulcer. World J Gastroenterol 2003;9:2338-2340.

$>93$ Chan FK, Hung LC, Suen BY, Wong VW, Hui AJ, Wu JC, Leung WK, Lee YT, To KF, Chung SC, Sung JJ: Celecoxib versus diclofenac plus omeprazole in high-risk arthritis patients: results of a randomized double-blind trial. Gastroenterology 2004;127:1038-1043.

94 Chan FK, Ching JY, Hung LC, Wong VW, Leung VK, Kung NN, Hui AJ, Wu JC, Leung WK, Lee VW, Lee KK, Lee YT, Lau JY, To KF, Chan HL, Chung SC, Sung JJ: Clopidogrel versus aspirin and esomeprazole to prevent recurrent ulcer bleeding. N Engl J Med 2005; 352:238-244.

95 Horvat D, Vcev A, Soldo I, Timarac J, Dmitrovic B, Misevic T, Ivezic Z, Kraljik N: The results of Helicobacter pylori eradication on repeated bleeding in patients with stomach ulcer. Coll Antropol 2005;29:139-142. 
\$96 Hung LC, Ching JY, Sung JJ, To KF, Hui AJ, Wong VW, Leong RW, Chan HL, Wu JC, Leung WK, Lee YT, Chung SC, Chan FK: Long-term outcome of Helicobacter pylorinegative idiopathic bleeding ulcers: a prospective cohort study. Gastroenterology 2005;128:1845-1850.

97 Cooper GS, Yuan Z, Rosenthal GE, Chak A, Rimm AA: Lack of gender and racial differences in surgery and mortality in hospitalized Medicare beneficiaries with bleeding peptic ulcer. J Gen Intern Med 1997;12: 485-490.

$\checkmark 98$ Kapetanakis AM, Kyprizlis EP, Tsikrikas TS: Efficacy of repeated therapeutic endoscopy in patients with bleeding ulcer. Hepatogastroenterology 1997;44:288-293.

-99 Thomopoulos K, Katsakoulis E, Vagianos C, Mimidis K, Margaritis V, Nikolopoulou $\mathrm{V}$ : Causes and clinical outcome of acute upper gastrointestinal bleeding: a prospective analysis of 1534 cases. Int J Clin Pract 1998; 52:547-550.

100 Lakhwani MN, Ismail AR, Barras CD, Tan WJ: Upper gastrointestinal bleeding in Kuala Lumpur Hospital, Malaysia. Med J Malaysia 2000;55:498-505.

101 Ruigómez A, García Rodríguez LA, Hasselgren G, Johansson S, Wallander MA: Overall mortality among patients surviving an episode of peptic ulcer bleeding. J Epidemiol Community Health 2000;54:130-133.
102 Brock J, Sauaia A, Ahnen D, Marine W, Schluter W, Stevens BR, Scinto JD, Karp H, Bratzler D: Process of care and outcomes for elderly patients hospitalized with peptic ulcer disease: results from a quality improvement project. JAMA 2001;286:19851993.

103 Adamopoulos AB, Efstathiou SP, Tsioulos DI, Tzamouranis DG, Tsiakou AG, Tiniakos D, Mountokalakis TD: Bleeding duodenal ulcer: comparison between Helicobacter pylori positive and Helicobacter $p y$ lori negative bleeders. Dig Liver Dis 2004; 36:13-20.

104 Duggan JM, Zinsmeister AR, Kelly KA, Melton LJ 3rd: Long-term survival among patients operated upon for peptic ulcer disease. J Gastroenterol Hepatol 1999; 14: 1074-1082.

105 Sillakivi T, Yang Q, Peetsalu A, Ohmann C: Perforated peptic ulcer: is there a difference between Eastern Europe and Germany? Copernicus Study Group and Acute Abdominal Pain Study Group. Langenbecks Arch Surg 2000;385:344-349.

106 Lee FY, Leung KL, Lai BS, Ng SS, Dexter S, Lau WY: Predicting mortality and morbidity of patients operated on for perforated peptic ulcers. Arch Surg 2001;136:90-94.

107 Somboonpanya P: Surgery for perforated peptic ulcers at Prachomklao Hospital. J Med Assoc Thai 2002;85:1003-1007.
108 Rahuman MM, Saha AK, Rahim A: Experience of peptic ulcer perforation over a decade in a teaching hospital of southern Bangladesh. Ceylon Med J 2003;48:53-55.

109 Ozalp N, Zulfikaroglu B, Bilgic I, Koc M: Evaluation of risk factors for mortality in perforated peptic ulcer in Ankara Numune Teaching Hospital, Ankara, Turkey. East Afr Med J 2004;81:634-637.

110 Veliyev NA, Merrell RC: Differentiated approach to surgical treatment of patients with perforated duodenal ulcer. Chirurgia (Bucur) 2004;99:119-123.

111 Ersumo T, Y WM, Kotisso B: Perforated peptic ulcer in Tikur Anbessa Hospital: a review of 74 cases. Ethiop Med J 2005;43: 9-13.

112 Lunevicius R, Morkevicius M: Risk factors influencing the early outcome results after laparoscopic repair of perforated duodenal ulcer and their predictive value. Langenbecks Arch Surg 2005;390:413-420.

113 Christensen S, Riis A, Norgaard M, Thomsen RW, Tonnesen EM, Larsson A, Sorensen HT: Perforated peptic ulcer: use of pre-admission oral glucocorticoids and 30 day mortality. Aliment Pharmacol Ther 2006;23:45-52. 